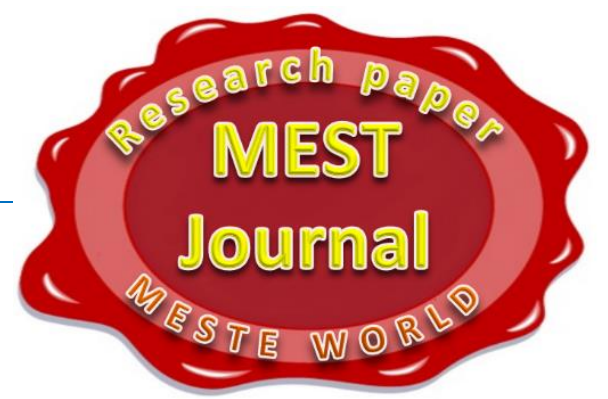

\title{
INFLUENCE OF AN SME'S SIZE ON THE INTEGRATION OF DIGITAL TECHNOLOGIES AND INTERNET USAGE
}

\section{Milanka Bogavac}

Faculty of Business and Law of the "Union - Nikola Tesla" University in Belgrade, Belgrade, Serbia

\section{Zoran Čekerevac}

Faculty of Business and Law of the "Union - Nikola Tesla" University in Belgrade, Belgrade, Serbia

OMESTE

JEL Category: D83, L15, L86

\begin{abstract}
This paper presents an overview of a part of the research performed in order to define the ways and criteria for determining the degree of success of the digitalization of SMEs. During this research, a new Index of the Digitalization of SMEs was defined. It enables a fast assessment of the digitalization level for each SME. The index itself includes four dimensions, of which the third and fourth, Integration of digital technologies and Internet usage, were considered in this paper. The first considered dimension describes the level of digital technology use and electronic commerce. The second dimension focuses on Internet communications and Internet transactions. Considering the importance of using the Internet in the business of most SMEs, the paper presents an analysis of the relationship between the use of the Internet and the connection of SMEs to the Internet. After presenting the methodology of the research, there are shown the results of the research obtained using this methodology. Three research questions supported by appropriate hypotheses, null and alternative, are discussed. Particular emphasis in the research is placed on determining the impact of the size of SMEs on Internet usage. Based on the research, it was established that there is a correlation between the size of SMES and the level of integration of digital technologies, but there is no correlation between the size of SMEs and the dimension "Internet usage". This work can usefully serve anyone involved in the digitalization of SMEs and/or in the re-engineering of SMEs' business processes.
\end{abstract}

Keywords: digitalization, SME, Internet, IDSME index, business process, reengineering.

\section{INTRODUCTION}

In the last decade of the XX century, and at the beginning of this century, the entrepreneurship and the micro, small and medium-sized

Address of the corresponding author: Milanka Bogavac

䒠bogavac.milanka@gmail.com enterprises (SMEs) have appeared as possible ways of survival for many people. The small, legal entities with precisely defined goals can be established with small investments. They can successfully operate, but in case of their failure, there will be no major earthquakes. The next good fact is that SMEs can quickly adapt to new business conditions. But, their size often can cause problems because of their limited 
resources, both, the material and human resources. SMEs are discussed in a number of literary sources, such as, for example, (Chang, 2014), (Curran \& Keynes, 1999), (Bolton, 1971), (Champaneri, 2017), (Schumpeter, 1934; 1983; 2008), etc. So, we will not deal with this topic here.

Considering available data, the current level of technology and trends in development, and the importance of SMEs, and bearing in mind the ubiquity of information technologies, digitalization is imposed as an undeniable influence on the functioning of SMEs. Digitalization is a term that is widely used nowadays.

Many indices have been created to point out to the level of digitalization of individual economies and countries, e.g. DESI - Digital Economy and Society Index (Benini, 2018), I-DESI International
Digital Economy Index (Foley, Sutton, Wiseman, Green, \& Moore, 2018), EDI - Enabling Digitalization Index (Hermes, 2018), GCI - Global Connectivity Index (Huawei, 2018), and others, but the area of SMEs remained neglected. No index is focused on SMEs. In order to alleviate this deficiency, we created a new index, the Index of Digitalization of SMEs (IDSME).

\section{INDEX OF DIGITALIZATION OF SMES (IDSME)}

The IDSME index represents a contribution to the exploration of the impact of digitalization on individual SME. It allows SMEs to carry out selfevaluation and determine to what level they are digitalized and on what they need to pay attention to in their development plans.

Table 1 The structure of IDSME dimensions Integration of digital technologies and Internet usage

\begin{tabular}{|c|c|c|c|c|c|}
\hline Dimension & Sub-dimension & Indicator & Criterion & $\min$ & $\max$ \\
\hline \multirow{11}{*}{$\begin{array}{l}\text { 3. Integration of } \\
\text { digital } \\
\text { technologies } \\
\qquad(w=45 \%)\end{array}$} & \multirow{8}{*}{$\begin{array}{l}\text { 3a. Use of digital } \\
\text { technologies } \\
\qquad(\mathrm{w}=50 \%)\end{array}$} & $\begin{array}{l}\text { 3a1. Possession of an own } \\
\text { website }\end{array}$ & $\begin{array}{l}\text { Possession of an active } \\
\text { website }\end{array}$ & 0 & 1 \\
\hline & & $\begin{array}{l}\text { 3a2. Possession of an or } \\
\text { more accounts on social } \\
\text { networks }\end{array}$ & $\begin{array}{l}\text { Possession of an or more } \\
\text { active accounts on social } \\
\text { networks }\end{array}$ & 0 & 1 \\
\hline & & $\begin{array}{l}\text { 3a3. Keeping records } \\
\text { electronically }\end{array}$ & $\begin{array}{l}\text { Possession of dedicated } \\
\text { software }\end{array}$ & 0 & 1 \\
\hline & & $\begin{array}{l}\text { 3a4. Using of B2B } \\
\text { e-business models }\end{array}$ & $\begin{array}{l}\text { Internet activities in the last } \\
\text { three months }\end{array}$ & 0 & 1 \\
\hline & & $\begin{array}{l}\text { 3a5. Using of B2G } \\
\text { e-business models }\end{array}$ & $\begin{array}{l}\text { Internet activities in the last } \\
\text { year }\end{array}$ & 0 & 1 \\
\hline & & 3a6. Using cloud computing & $\begin{array}{l}\text { Possession of an active } \\
\text { Cloud account }\end{array}$ & 0 & 1 \\
\hline & & $\begin{array}{l}\text { 3a7. Using some decision } \\
\text { support tool }\end{array}$ & $\begin{array}{l}\text { Possession of dedicated } \\
\text { software }\end{array}$ & 0 & 1 \\
\hline & & 3a8. Using automation & Possession of equipment & 0 & 1 \\
\hline & \multirow{3}{*}{$\begin{array}{l}\text { 3b. Electronic } \\
\text { commerce } \\
\qquad(\mathrm{w}=50 \%)\end{array}$} & 3b1. Online selling & Sales made online & 0 & 1 \\
\hline & & 3b2. E-commerce turnover & $\%$ of the total turnover & 0 & 33 \\
\hline & & $\begin{array}{l}\text { 3b3. Cross-border online } \\
\text { sales }\end{array}$ & $\%$ of the total turnover & 0 & 25 \\
\hline \multirow{6}{*}{$\begin{array}{l}\text { 4. Internet usage } \\
\text { (w = 25\%) }\end{array}$} & \multirow{4}{*}{$\begin{array}{l}\text { 4a. Communication } \\
\qquad(w=50 \%)\end{array}$} & $\begin{array}{l}\text { 4a1. Individual video calls or } \\
\text { video conferences }\end{array}$ & $\begin{array}{l}\text { Internet activities in the last } \\
\text { year }\end{array}$ & 0 & 1 \\
\hline & & 4a2. Use of e-mail & $\begin{array}{l}\% \text { of e-mails in total } \\
\text { correspondence }\end{array}$ & 0 & 90 \\
\hline & & $\begin{array}{l}\text { 4a3. Participation in social } \\
\text { networks }\end{array}$ & $\begin{array}{l}\text { Frequency of using social } \\
\text { networks (never, rarely, at } \\
\text { least once a month, weekly, } \\
\text { daily) }\end{array}$ & 0 & 4 \\
\hline & & 4a4. Intranet possession & Network possession & 0 & 1 \\
\hline & \multirow{2}{*}{$\begin{array}{l}\text { 4b. Transactions } \\
\qquad(\mathrm{w}=50 \%)\end{array}$} & 4b1. E-banking & $\begin{array}{l}\% \text { of electronic- in total } \\
\text { banking- transactions }\end{array}$ & 0 & 90 \\
\hline & & $\begin{array}{l}\text { 4b2. Purchasing over the } \\
\text { Internet }\end{array}$ & $\begin{array}{l}\% \text { Internet shopping in total } \\
\text { purchases }\end{array}$ & 0 & 25 \\
\hline
\end{tabular}

Source: (Bogavac \& Čekerevac, 2019) 
The IDSME can also measure the progress of SMEs in the digitalization process. As such, it brings a combination of relevant indicators weighted within sub-dimensions and dimensions.

The IDSME index allows four main types of analyses (Bogavac, 2019):

- Overall Impact Assessment: to achieve the general performance characteristics of an SME by observing its overall index and results of the main dimensions of the index.

- Zooming: to identify areas where the performance of SMEs could be improved by analyzing the results of the sub-dimensions of the index and the individual indicators.

- Tracking: to assess if there is progress over time.

- Comparative analysis: to compare the successes of SMEs according to index results, comparing SMEs in similar activities to identify the need to improve the business environment.

The structure of the IDSME index is explained in detail in (Bogavac, 2019) and (Bogavac \& Čekerevac, 2019), so only the part that relates to this research will be presented here.

The structure of these two dimensions is shown in Table 1. In the table, the weights of the corresponding sub-dimensions and dimensions are indicated by $\mathrm{w}$. The weighting is explained in more detail in sub-section 3.2.

\section{RESEARCH}

This research was conducted on SMEs in Russia, Serbia, and Slovakia. The aim was to measure the significance of the digitalization of business processes to SMEs individually and globally. In this paper, the accent is placed on two dimensions, Integration of digital technologies in SMEs and Internet usage.

\subsection{Methodology}

This research is exploratory with elements of explanatory and descriptive. Within the research, relevant research objects were identified and explained. Within the descriptive analysis, the phenomena are broken down into sections sufficient for the analysis to be successfully carried out and that proper legality can be observed. In doing so, both deduction and induction were used.

The research used an empirical method as an analytical method that enables reliable conclusions on the interdependence of certain observed elements and trends in individual phenomena. The statistical analysis covered the relevant data that enabled the detection of the legality of mass events covered by this analysis. In doing so, one should be aware that the statistics are not almighty and that the results obtained should always be accepted with the reserve. The statistically obtained results give a quantitative determination of some phenomenon, but not qualitative. The qualitative determination is obtained by the induction method. The conclusions thus obtained, from the individual to the general, can depend on the one who performs the analysis. A particular problem in statistical data processing is the size and credibility of the sample. This analysis was done based on a survey conducted in Russia, Slovakia, and Serbia. Although the samples should be randomly selected, it was not possible to provide absolute randomness of the samples in this survey. The reasons are numerous, starting from the incomplete data from the databases with SME addresses that were used to select the sample, to the level of those who filled out the survey. Since the SMEs and their addresses were mostly obtained by Internet mining, the results are probably somewhat more favorable than those that would be obtained if in the survey they were included and those companies that are not in any form present on the Internet. However, this did not adversely affect the results, because the topic of work is focused on studying the impact of digitalization on the work of SMEs that use the Internet in some way.

The research was carried out by checking hypotheses. The basic goals of setting the hypotheses are directing to the problem and the connecting theoretical assumptions with the experiential reality. Hypotheses have been tested based on relevant data using modern mathematical tools in the following way (Bogavac \& Čekerevac, 2019):

1. Defining the boundary of significance;

2. Writing hypotheses, zero and alternative; 
3. Selection of sample or samples, and calculation of parameters;

4. Determination of the limits of rejecting the zero hypotheses;

5. Determining whether the zero hypotheses can be rejected; and

6. Defining and presenting conclusions according to tested hypotheses.

\subsection{Normalization, weighting, and aggregation}

Based on the structure shown in Table 1, it is seen that the dimensions are composed of subdimensions and that the sub-dimensions include many indicators. To obtain useful results, it is necessary to normalize the indicators and weighting of the indicators and sub-dimensions. To determine the value of the IDSME index, we need also to carry out the weighting of dimensions. Normalization of the indicators was performed using the min-max method by the linear projection of each indicator on a scale in the range 0 to 1 . The zero corresponds to the minimum value and one to the maximum value. The criteria and limit values of the indicators are shown in Table 1, the last three columns. The same minmax method was used for sub-dimensions normalization. Thus, each of the sub-dimensions was ranged from zero to one, which allowed the dimensions to have values between zero and one after weighting.

It is difficult, practically impossible, to choose dimensions, sub-dimensions, and indicators so that they reflect the state and to have the same impact. To overcome this challenge, weighting appears as a very useful method. As written in chapter 2, the applied correction coefficients are marked with $\mathrm{w}$, and their values are shown with the corresponding dimensions and subdimensions in Table 1. The values of the indicators are not weighted.

The aggregation of indicators in IDSME dimensions was done on the way that the indicators were aggregated into the subdimensions ( $\operatorname{step} 1$ ), and then the weighted values of the sub-dimensions were aggregated into dimensions (step 2) as follows:

$$
C=0,5 \cdot C_{3 a}^{\prime}+0,5 \cdot C_{3 b}^{\prime}
$$

where
$C-$ a value of dimension 3 , Integration of digital technologies

$C_{3 a}^{\prime}$ - the normalized value of the subdimension 3a. Use of digital technologies = $\underline{\sum_{i=1}^{i=8} C_{3 a i}}$

$C_{3 b}^{\prime}$ - the normalized value of the subdimension $3 b$. Electronic commerce = $\frac{C_{3 b 1}+C_{3 b 2}^{\prime}+C_{3 b 3}^{\prime}}{3}$

Similarly, the values $D$ of the dimension 4 , Internet Usage, have been obtained:

$$
D=0,5 \cdot D_{4 a}^{\prime}+0,5 \cdot D_{4 b}^{\prime}
$$

$D_{4 a}^{\prime}$ - the normalized value of the sub-

$$
\text { dimension } 4 a \text {. Communication = }
$$

$\frac{D_{4 a 1}+D_{4 a 2}^{\prime}+D_{4 a 3}^{\prime}+D_{4 a 4}}{4}$

$D_{4 b}^{\prime}$ - the normalized value of the sub-

dimension $4 b$. Transactions $=\frac{D_{4 b 1}^{\prime}+D_{4 b 2}^{\prime}}{2}$

Normalized values are marked by accents, and the other tags correspond to the tags in Table 1.

In all cases, the min-max normalization was made according to the general formula

$$
x^{\prime}=\frac{x-\min (x)}{\max (x)-\min (x)}
$$

\subsection{Sample}

In this research, E-mails with the survey forms were sent to 847 addresses in Serbia, Russia, and Slovakia. E-mail surveys provided the opportunity to fill in the poll online or to return the completed form to the sender's address. Respondents were given the opportunity to fill in the survey anonymously. The number of employees, which is a key figure for all subsequent calculations, was an obligatory data. In addition to this, a threelanguage survey was set up using the Google Forms platform. A total of 236 useful answers were obtained. The response rate in the survey was $27.98 \%$ which can be considered as an excellent response since the survey was voluntary and unpaid. Nevertheless, it should be noted that the survey was supported by the Institute of Humanities in St. Petersburg, the Majkop State Technological University in Maykop, both from the Russian Federation and the School of Economics and Public Administration in Bratislava, Slovakia. The research in Serbia was conducted with the 
help of the Serbian Chamber of Commerce in Belgrade.

\subsection{Dimension - Integration of digital technologies}

Dimension the Integration of digital technologies focuses on the degree to which SMEs are ready to use digital technologies in their business regardless they are used on the Internet, or they are part of the intranet or even they are used on individual computers. Therefore, the dimension is divided into two sub-dimensions (Bogavac \& Čekerevac, 2019):

- The use of digital technologies, and

- Electronic commerce
The "The use of digital technologies" subdimension consists of eight indicators that indicate whether the SME has its website, social network accounts, whether it keeps its records electronically, and uses B2B and B2G business models, cloud computing, tools for the decision support, and automation.

The "Electronic commerce" sub-dimension includes online selling; e-commerce turnover; and cross-border online sales.

Before calculating the value of the dimension Integration of digital technologies, an analysis was made, and it was established that this dimension is normally distributed as shown in Figure 1.

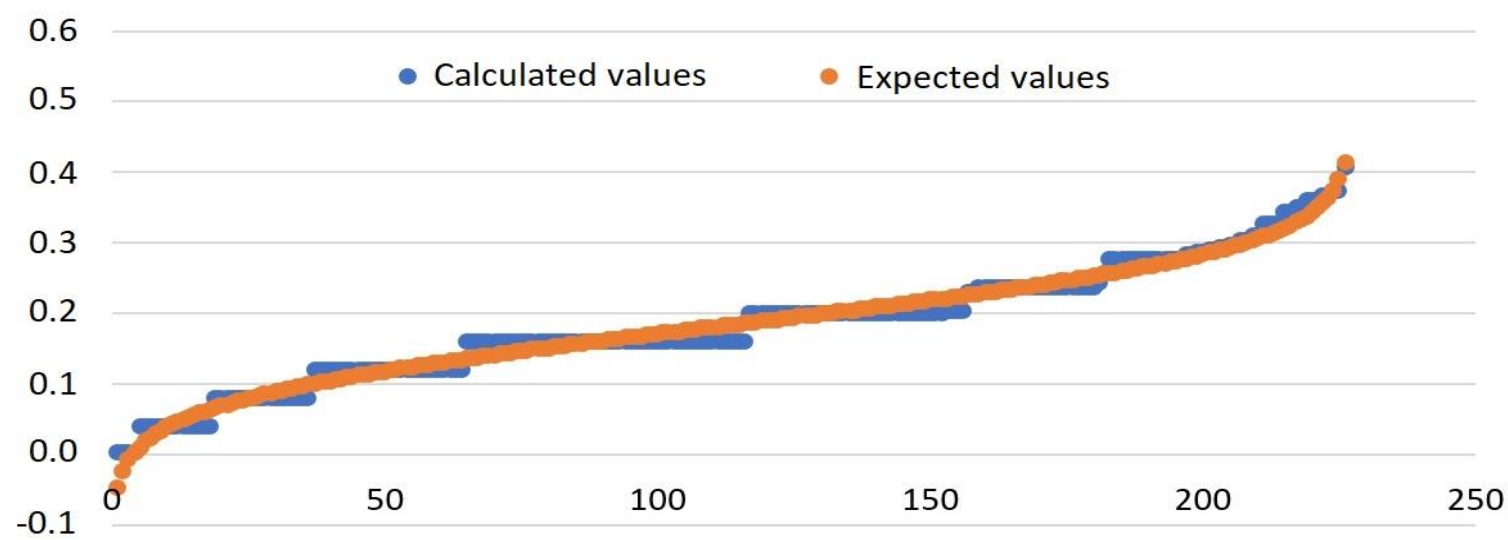

Fig. 1 The distribution of the IDSME dimension Integration of digital technologies

Figure 1 shows that the calculated values of the dimension Integration of digital technologies coincide with the ideal curve of the normal distribution for the corresponding sets of data. Visible differences occur only there where more SMEs have achieved the same, maximum, result. Also, there are several micro-enterprises that achieved score 0 , so their cumulative impact led to the expected value of less than zero, which is impossible. When repetitions are absent from consideration, the calculated dimension values are virtually identical to the theoretical values for the normal distribution.

During the research, the first research question (A) was raised: What is the relationship between the size of SMEs and the integration of digital technologies in SMEs expressed through the dimension "Integration of digital technologies" of the IDSME index?

To investigate this relationship in the survey, questions were asked about:
- a possession of:

- an active website,

- an open order on social networks,

- business software that SMEs use in their business, and

- online store

- using of:

- the B2B business models in the last three months,

- the B2G business model in the past year,

- cloud computing

- the decision support tool, and

- automation of business processes,

- E-commerce turnover share in total turnover, and

- the cross-border share of online sales.

The null hypothesis for the first research question can be set up in the form of:

$\mathrm{H}_{\mathrm{A} 0}$ : There is no relationship between the size of SMEs and the integration of digital technologies into their business expressed 
through the dimension Integration of digital technologies of the IDSME index.

The alternative hypothesis for the first research question can be set up in the form of:

$\mathrm{H}_{\mathrm{A} 1}$ : There is a relationship between the size of SMEs and the integration of digital technologies into their business expressed through the dimension Integration of digital technologies of the IDSME index.
Based on the results of the survey, the null hypothesis was verified by the MS Excel program's data analysis tool Regression. Results of statistical data processing for the relationship between the size of SMEs and their ability to integrate the digital technologies expressed through the dimension "Connection to the Internet" of the IDSME Index are shown in Table 2.

Table 2 Results of statistical data processing for the relationship between the size of SMEs and their ability to integrate the digital technologies expressed through the IDSME dimension "Integration of digital technologies"

\begin{tabular}{lr}
\hline \multicolumn{2}{c}{ Regression Statistics } \\
\hline Multiple R & 0.1923787 \\
R Square & 0.0370096 \\
Adjusted R Square & 0.0327105 \\
Standard Error & 0.0832528 \\
Observations & 226 \\
\hline
\end{tabular}

\begin{tabular}{|c|c|c|c|c|c|c|}
\hline \multirow[t]{2}{*}{ ANOVA } & \multirow[b]{2}{*}{$d f$} & \multirow[b]{2}{*}{ SS } & \multirow[b]{2}{*}{$M S$} & \multirow[b]{2}{*}{$F$} & \multirow[b]{2}{*}{ Significance $F$} & \\
\hline & & & & & & \\
\hline Regression & 1 & 0.05967 & 0.05967 & 8.608745 & 0.003693516 & \\
\hline Residual & 224 & 1.55255 & 0.00693 & & & \\
\hline \multirow[t]{2}{*}{ Total } & 225 & 1.61222 & & & & \\
\hline & Coefficients & $\begin{array}{c}\text { Standard } \\
\text { Error }\end{array}$ & $t$ Stat & $P$-value & Lower 95\% & Upper 95\% \\
\hline Intercept & 0.170254 & 0.00683 & 24.94064 & 0.000000 & 0.156802 & 0.183706 \\
\hline X Variable 1 & 0.000258 & 0.00009 & 2.93407 & 0.003694 & 0.000085 & 0.000431 \\
\hline
\end{tabular}

The obtained result for the Pearson coefficient $\rho=0.192379$ and the $p$-value less than 0.05 , they reject the null hypothesis that there is no correlation between the size of SMEs and the integration of digital technologies into their business expressed through the dimension "Integration of digital technologies" of the IDSME index. The correlation is at a level of poor correlation.

The linear regression equation on the basis of the obtained results gets a shape

$$
y \approx 0,170254+2,58 * 10^{-4} * x
$$

where $\boldsymbol{x}$ is the number of employees in SMEs, and $\boldsymbol{y}$ is the value of the dimension Integration of digital technologies.

\subsection{Dimension - Internet usage}

The Internet Usage dimension focuses on the types of activities that SMEs have on the Internet, primarily on communications and business transactions. Therefore, two sub-dimensions were created:

- Communication and

- Transactions.

The sub-dimension, Communication includes four indicators relating to external and internal communications:

- video calls (single or video conferencing),

- use of e-mail,

- participation on social networks, and

- possession of intranets.

The use of video calls and the possession of intranets are encoded with 1 (use, has) and 0 (not 
used, no). The use of e-mail is viewed as a percentage share in total written correspondence, and participation in social networks is differentiated according to the frequency of use of social networks ranging from 0 (never used) to 1 (used daily), with values of 0.25 (rare), 0.5 (once a month) and 0.75 (once a week).

The sub-dimension, Transactions describes the propensity of SMEs, Internet users, to execute online transactions. It focuses on two indicators:

- electronic banking, and

- $\quad$ shopping via the Internet.

As a criterion for electronic banking, the percentage of electronic in total banking transactions was taken.
For the indicator Internet shopping, the share of epurchases was taken in relation to the total purchase. In order to provide more relevant results, the limit value for this indicator was taken as $25 \%$ of the total purchase, and all above this value was encoded by the value 1 .

The criteria for each of the indicators are shown in Table 1.

Before further analysis and calculating the value of the dimension of Internet usage, an analysis was made to see whether this dimension is normally distributed. The results are shown in Figure 2.

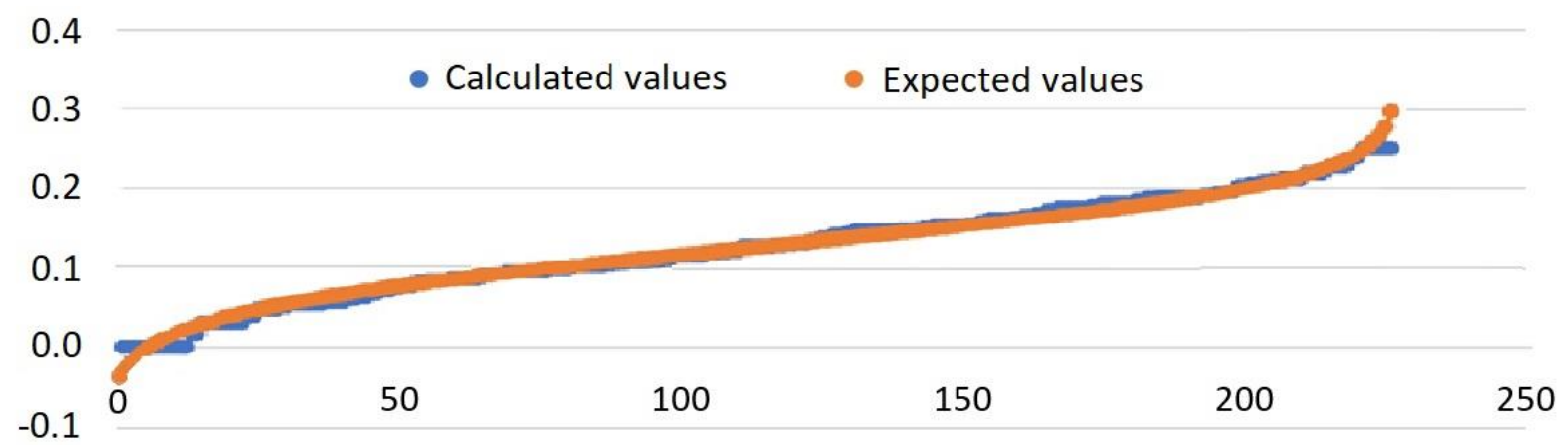

Fig. 2 The distribution of the IDSME dimension Internet usage

Source: Author

Figure 2 shows that the calculated values of the dimension Internet usage coincide with the ideal curve of the normal distribution for the corresponding sets of data. Certain deviations on the tails of the diagram and the negative value of the expected values for micro-companies can be explained in the same way as explained in relation to Figure 1.

In connection with the use of the Internet, the second research question (B) was raised:

What is the relationship between the size of SMEs and the use of the Internet in SMEs expressed through the "Internet Usage" dimension of the IDSME index?

Under "Internet Usage", here are meant:

- $\quad$ using the Internet for video communications in the past year,

- E-mail share in total postal communication of SMEs,

- $\quad$ frequency of using social networks by SMEs,

- possession of intranets
- electronic banking share in total banking transactions,

- the share of electronic purchases in total purchases.

The null hypothesis for this research question can be set in the form:

$\mathrm{H}_{\mathrm{B} 0}$ : There is no correlation between the size of SMEs and the use of the Internet within the SME business, expressed through the "Internet Usage" dimension of the IDSME index.

An alternative hypothesis for this research question can be defined in the form:

$\mathrm{H}_{\mathrm{B} 1}$ : There is a correlation between the size of SMEs and the integration of digital technologies into their business, expressed through the dimension "Internet Usage" of the IDSME index.

The null hypothesis was checked with the same tools and in the same way as explained in the case of the first research question. The results of statistical data processing are shown in Table 3. 
In this case, the value of Pearson's correlation coefficient is $\rho=0.066627$, which is significantly less than 0.3 and very close to zero. The P-value is significantly higher than the limit value of 0.05 , so the results obtained for this set of data do not reject the null hypothesis $\mathrm{H}_{\mathrm{B} o}$ that there is no correlation between the size of SMEs and the use of the Internet in the context of SME operations expressed through the "Internet Usage" dimension of the IDSME index while rejecting the alternative hypothesis of $\mathrm{H}_{\mathrm{B} 1}$ that there is a correlation between the size of SMEs and the integration of digital technologies into their business expressed through the "Internet usage" dimension of the IDSME index. Looking at the limit values of Variable1, Lower $95 \%$, and Upper 95\%, one can see that the field includes zero, indicating that these two dimensions are not interdependent.

Table 3 Results of statistical data processing for the relationship between the size of SMEs and the use of the Internet in the framework of SME operations expressed through the IDSME dimension "Internet Usage"

\begin{tabular}{|c|c|c|c|c|c|}
\hline \multicolumn{2}{|c|}{ Regression Statistics } & & & & \\
\hline Multiple R & 0.066627 & & & & \\
\hline R Square & 0.004439 & & & & \\
\hline Adjusted R Square & -0.000005 & & & & \\
\hline Standard Error & 0.062713 & & & & \\
\hline Observations & 226 & & & & \\
\hline \multicolumn{6}{|l|}{ ANOVA } \\
\hline & $d f$ & SS & MS & $F$ & Significance $F$ \\
\hline Regression & 1 & 0.003928 & 0.003928 & 0.998815 & 0.318676 \\
\hline Residual & 224 & 0.880964 & 0.003933 & & \\
\hline Total & 225 & 0.884892 & & & \\
\hline
\end{tabular}

\begin{tabular}{|c|c|c|c|c|c|c|}
\hline & & Standard & & & & \\
\hline & Coefficients & Error & t Stat & P-value & Lower 95\% & Upper 95\% \\
\hline Intercept & 0.121301 & 0.005142 & 23.589457 & 0.000000 & 0.111168 & 0.131434 \\
\hline X Variable 1 & 0.000066 & 0.000066 & 0.999407 & 0.318676 & -0.000064 & 0.000197 \\
\hline
\end{tabular}

Since we have established that there is no correlation between the size of SMEs and the use of the Internet, a new, the third research question (C) has appeared:

What is the relationship between the use of the Internet in SMEs and their connection to the Internet in the manner defined by the IDSME model?

Significant on this issue is that it allows one to see how the Internet is used, or how many employees use video communications, e-mail, social networking, e-banking, and online purchases.

In this analysis, Connectivity to the Internet is considered an independent variable, and Internet usage is a dependent variable. The null hypothesis for a research question $\mathrm{C}$ can be set in the form:
$\mathrm{H}_{\mathrm{c} 0}$ : There is no correlation between the use of the Internet by employees in SMEs and the connection of SMEs to the Internet according to the indices included in the "Internet Usage" and "Internet Connection" dimensions of the IDSME index.

An alternative hypothesis for the research question $\mathrm{C}$ can be defined in the form:

$\mathrm{H}_{\mathrm{c} 1}$ : There is a correlation between the use of the Internet by employees of SMEs and SMEs' connection to the Internet according to the indices included in dimensions "Using the Internet" and "Internet Connection" IDSM index.

The null hypothesis was checked with the same tools and in the same way, as it was already explained. The results of statistical data processing are shown in Table 4. 
Based on the results shown in Table 4, it can be seen that Pearson's coefficient, in this case, has a value of $\rho=0.27048$ and that the $p$-value is statistically significant and significantly lower than the set limit value of 0.05 . So the null hypothesis $\mathrm{H}_{\mathrm{co}}$ that there is no correlation between the use of the Internet by employees in SMEs and the connection of SMEs to the Internet according to the indices included in the "Internet Usage" and
"Internet Connection" dimensions of the IDSME index can be rejected at the expense of the alternative $\mathrm{H}_{\mathrm{C} 1}$ hypothesis that there is a connection between the use of the Internet by employees in SMEs and SME linkages to the Internet according to the parameters covered by the dimensions "Internet Usage" and "Internet Connection" IDSME index.

Table 4 The results of statistical data processing for the relationship between the use of the Internet and the connection of SMEs to the Internet

\begin{tabular}{|c|c|c|c|c|c|}
\hline \multicolumn{2}{|c|}{ Regression Statistics } & & & & \\
\hline Multiple R & 0.27048 & & & & \\
\hline R Square & 0.07316 & & & & \\
\hline Adjusted R Square & 0.06902 & & & & \\
\hline Standard Error & 0.06051 & & & & \\
\hline Observations & 226 & & & & \\
\hline \multicolumn{6}{|l|}{ ANOVA } \\
\hline & $d f$ & SS & MS & $F$ & Significance $F$ \\
\hline Regression & 1 & 0.064736 & 0.064736 & 17.680762 & 3.7777E-05 \\
\hline Residual & 224 & 0.820155 & 0.003661 & & \\
\hline Total & 225 & 0.884892 & & & \\
\hline
\end{tabular}

\begin{tabular}{lccccrc}
\hline & \multicolumn{3}{c}{ Standard } & & & Upper \\
& Coefficients & Error & t Stat & P-value & Lower 95\% & $95 \%$ \\
\hline Intercept & 0.0851 & 0.0102 & 8.3826 & $5.756 \mathrm{E}-15$ & 0.06510 & 0.10512 \\
X Variable 1 & 0.4494 & 0.1069 & 4.2048 & $3.778 \mathrm{E}-05$ & 0.23881 & 0.66007 \\
\hline
\end{tabular}

Source: Authors

Correlation is at a level of poor correlation.

The linear regression equation on the basis of the obtained results gets a shape

$$
y \approx 0,0851+0,4494 * x
$$

where $\boldsymbol{x}$ is the value of the Internet connection dimension, and $\boldsymbol{y}$ is the value of the Internet usage dimension.

\section{CONCLUSIONS}

The research has shown that the digitalization process is in an unstoppable rise and that most of the SMEs follow this trend in the hope that they will be able to exploit its potential.

The IDSME index has proven to be a tool that allows SMEs to see their achievements in the field of digitalization, as well as the way forward. The size of SME affects the level of integration of digital technologies into the company's business but does not affect the level of Internet usage in the business. Also, it has been proven that there exists a correlation between the level of connection of SMEs with the Internet and the level of Internet use for the business purposes of SMEs.

This research was focused on the digitalization of SMEs and did not include other employee-related Internet activities. Given the huge number of smart mobile phones used by employees in SMEs, it can be expected that the use of the Internet is higher than that obtained with the IDSME index. It is not possible to set a clear border between the use of the Internet for private and business purposes. The experience that employees acquire when using the Internet for private purposes is also used for business purposes. 
The expected introduction of $5 \mathrm{G}$ networks will open new opportunities for the business and development of SMEs, and will also influence the change of existing criteria in relation to IDSME index indicators. However, this will not be a limiting factor for the implementation of the IDSME index.

\section{WORKS CITED}

Benini, F. (2018, 10 26). The Digital Economy and Society Index (DESI). Retrieved from European Commission - Digital Single Market: https://ec.europa.eu/digital-single-market/en/desi

Bogavac, M. (2019). Research on the Influence of Digitalization on Small and Medium Enterprises. Belgrade: ICIM+, Faculty of Business and Law, "Union - Nikola Tesla" University.

Bogavac, M., \& Čekerevac, Z. (2019, July 15). IDSME Index - New Method for Evaluation of SMEs Digitalization. (Z. Čekerevac, Ed.) MEST Journal, 7(2).

Bolton, J. (1971). Report of the Committee of Enquiry into Small Firms. London: HMSO.

Champaneri, J. (2017, 11 30). Business Population Estimates for the UK and Regions in 2017. Retrieved from Department for Business, Energy \& Industrial Strategy: https://assets.publishing.service.gov.uk/government/uploads/system/uploads/attachment_data /file/663235/bpe_2017_statistical_release.pdf

Chang, H.-J. (2014). A brief history of capitalism. How have we got here? In Economics, the user's guide (p. 384). Bloomsbury Press.

Curran, J., \& Keynes, M. (1999). The Role of the Small Firm in the UK Economy: Hot Stereotypes and Cool Assessments. SBRT Research Report, 48.

Foley, P., Sutton, D., Wiseman, I., Green, L., \& Moore, J. (2018). International Digital Economy and Society Index 2018. Luxembourg: Publications Office of the European Union. Retrieved from https://ec.europa.eu/digital-single-market/en/news/international-digital-economy-and-societyindex-2018

Hermes, E. (2018, 03 15). Enabling Digitalization Index 2018: Measuring digitagility. Retrieved from Euler Hermes: https://www.eulerhermes.com/en_global/media-news/news/enablingdigitalization-index-2018-measuring-digitagility.html

Huawei. (2018). Methodology. Retrieved from GCl - global connectivity index: https://www.huawei.com/minisite/gci/en/methodology.html

Schumpeter, J. A. (1934; 1983; 2008). The Theory of Economic Development: An Inquiry into Profits, Capital, Credit, Interest, and the Business Cycle. New Brunswick, New Jersey: Transaction Books.

Received for publication: $\quad 01.03 .2020$

Revision received: $\quad 25.04 .2020$

Accepted for publication: $\quad 01.07 .2020$

\section{How to cite this article?}

Style - APA Sixth Edition:

Bogavac, M., \& Čekerevac, Z. (2020, July 15). Influence of an SME's size on the integration of digital technologies and internet usage. (Z. Cekerevac, Ed.) MEST Journal, 8(2), 25-35. doi:10.12709/mest.08.08.02.04 
Style - Chicago Sixteenth Edition:

Bogavac, Milanka, and Zoran Čekerevac. 2020. "Influence of an SME's size on the integration of digital technologies and internet usage." Edited by Zoran Cekerevac. MEST Journal (MESTE) 8 (2): 25-35. doi:10.12709/mest.08.08.02.04.

Style - GOST Name Sort:

Bogavac Milanka and Čekerevac Zoran Influence of an SME's size on the integration of digital technologies and internet usage [Journal] // MEST Journal/ ed. Cekerevac Zoran. - Belgrade Toronto : MESTE, July 15, 2020. - 2 : Vol. 8. - pp. 25-35.

Style - Harvard Anglia:

Bogavac, M. \& Čekerevac, Z., 2020. Influence of an SME's size on the integration of digital technologies and internet usage. MEST Journal, 15 July, 8(2), pp. 25-35.

Style - ISO 690 Numerical Reference:

Influence of an SME's size on the integration of digital technologies and internet usage. Bogavac, Milanka and Čekerevac, Zoran. [ed.] Zoran Cekerevac. 2, Belgrade - Toronto : MESTE, July 15, 2020, MEST Journal, Vol. 8, pp. 25-35. 